\title{
Aquatic and Dry Land Weeds as Potential Renewable Fibers Resources for Paper
}

\author{
Tamrin $^{1}$, Filli Pratama ${ }^{1, *}$, Rahmad Hari Purnomo ${ }^{1}$, Nessia Davitri ${ }^{1}$ \\ ${ }^{I}$ Study Program of Agricultural Engineering, Faculty of Agriculture, Universitas Sriwijaya, 30662 Indralaya, South \\ Sumatra, Indonesia \\ *Corresponding Author: fillipratama@gmail.com Phone: +628153818913
}

Article history

\begin{tabular}{llll} 
Received & Received in revised form & Accepted & Available online \\
21 April 2017 & 18 May 2017 & 20 May 2017 & 30 May 2017 \\
\hline
\end{tabular}

\begin{abstract}
The investigation of aquatic and dry land weeds as fibers resources for paper making was carried out. The selected fiber resources of aquatic weeds were water hyacinth (Eicchornia crassipes) and water chestnuts (Eleocharis dulcis), and bladygrass (Imperata cylindrica) as the selected dry land weed. Research was designed as a factorial completely randomized design with two factors. The first factor was fibers origin (Eicchornia crassipes, Imperata cylindrica and Eleocharis dulcis) and the second factor was the fibers pulp slurry concentrations $(30 \%$, $50 \%$, and $70 \% \mathrm{v} / \mathrm{v}$ ). Results showed that the fibers origin and fibers pulp slurry concentration had significant effect $(\mathrm{p}<0.05)$ on the tensile strength, mass density, water absorption, and frictional resistance of paper. The interaction between the fibers origin and fibers pulp slurry concentration had significant effect on tensile strength, frictional resistance, water absorption; but had no significant effect on mass density of paper. The paper that was made of $70 \%(\mathrm{v} / \mathrm{v})$ of water hyacinth fiber pulp slurry showed the best characteristics with the tensile strength of $3.65 \mathrm{kgf}$ $\mathrm{mm}^{-1}$, mass density of $0.87 \mathrm{~g} \mathrm{~cm}^{-3}$, water absorption of $0.235 \mathrm{~g} \mathrm{~cm}^{-2}$, and frictional resistance of $0.028 \mathrm{~g} \mathrm{~cm}^{-2}$.
\end{abstract}

Keywords: water hyacinth, water chestnuts, bladygrass, paper

\begin{abstract}
Abstrak (Indonesian):Penelitian tentang sumber serat dari gulma air dan lahan kering untuk pengolahan kertas telah dilakukan. Gulma air yang potensial sebagai sumber serat adalah eceng gondok (Eicchornia crassipes) dan purun tikus (Eleocharis dulcis); alang-alang (Imperata cylindrica) sebagai sumber serat dari gulma lahan kering. Penelitian ini menggunakan rancangan acak lengkap yang disusun secara factorial dengan dua faktor. Faktor pertama adalah jenis gulma (Eicchornia crassipes, Imperata cylindrica, Eleocharis dulcis) dan faktor ke dua adalah konsentrasi penambahan bubur serat $(30 \%, 50 \%$, and $70 \% \mathrm{v} / \mathrm{v})$. Hasil penelitian menunjukkan bahwa jenis gulma dan konsentrasi penambahan bubur serat berpengaruh nyata $(\mathrm{p}<0,05)$ terhadap kekuatan tarik, massa jenis, absorpsi air dan ketahanan gesek. Interaksi antara jenis gulma dan konsentrasi penambahan bubur serat berpengaruh nyata terhadap kekuatan tarik, ketahanan gesek, abosrpsi air; tetapi berpengaruh tidak nyata terhadap massa jenis kertas. Kertas yang dibuat dari serat eceng gondok dengan konsentrasi bubur serat sebanyak $70 \%(\mathrm{v} / \mathrm{v})$ menghasilkan kertas dengan sifat mekanik dan fisik terbaik dengan kekuatan tarik $3,65 \mathrm{kgf} \mathrm{mm}^{-1}$, massa jenis $0,87 \mathrm{~g} \mathrm{~cm}^{-3}$, absorpsi air $0,235 \mathrm{~g} \mathrm{~cm}^{-2}$, dan ketahanan gesek $0,028 \mathrm{~g} \mathrm{~cm}^{-2}$.
\end{abstract}

Kata kunci: eceng gondok, purun tikus, alang-alang, kertas

\section{Introduction}

The raw material in paper is mostly natural fiber containing cellulose and hemicellulose, while other materials as additional material is in small amounts. Most paper making is from wood fibers. Due to environmental preservation, the use of wood fiber is restricted. Some paper industries use paper recycling in paper making; however the paper recycling could affect the mechanical and physical properties of paper [1]. There are some plants in tropical countries that could be resources of non-woods fiber for paper making such as water hyacinth (Eicchornia crassipes), water chestnut (Eleocharis dulcis), and bladygrass (Imperata cylindrica). Those plants are commonly known as weeds against cultivated plants. Weeds take nutrients and water from the soil and sunlight for photosynthesis, causing losses of production in terms of quality and quantity. E. crassipes and E. dulcis are aquatic weeds that disrupt water transportation in the river and lake [23]. I. cylindrica is not an aquatic plant; it can adapt and grow quickly in dry land. It is noxious due to its wide distribution to a wide range of climates and soils, as well as its high competitive ability with other crops. The dry leaves of I. cylindrica should be eliminated in order to prevent the start of wildfires. The use of fibers derives from those weeds for paper making might be an 
alternative to solve the problem. In addition, those weeds have quick regenerative properties; therefore they are potential as unlimited fibers resources for paper making.

Some research has been done on non-woods fibers for paper making; however most of the research was in the area of addition of some materials or coating in the process of paper making [4-8] such as polypropylene, resin, casein or starch; not as a single major raw material. The processing of paper making starts with pulping during which lignin is separated from cellulosic fibers. Lignin content in non-woods fiber is lower than that of hardwoods; therefore the pulping process in paper making of non-woods fibers is simpler than woods fibers. Different cellulosic fiber results in different mechanical and physical properties of paper. This study was associated with the mechanical and physical properties of paper made of fibers of $E$. crassipes, E. dulcis, and I. cylindrica. The paper produced would be environmental friendly paper which is safe to be used as a primary packaging for cookedfoods.

\section{Experimental Sections}

\subsection{Raw materials}

Materials for cellulosic fibers of water hyacinth (designated as WH), water chestnut (WC) and bladygrass (BG) were collected near the area of Universitas Sriwijaya, Ogan Ilir District, Inderalaya, south Sumatera, Indonesia.

\subsection{Preparation of alkaline solution}

The alkaline solution for separating lignin from fibers consisted of $\mathrm{NaOH}(75 \mathrm{~g})$ and $\mathrm{Na}_{2} \mathrm{CO}_{3}(25 \mathrm{~g})$ in a Liter of aquadest.

\subsection{Preparation of fiber pulp slurry}

The stalk of WH and WC as well as the leaves of BG were chopped into small fragments to a length of 1 $\mathrm{cm}$. Each of the weed as much as $2 \mathrm{~kg}$ and $4 \mathrm{~L}$ of alkaline solution were put in a stainless steel pot and brought to boil for an hour to separate lignin from fibers. The pulp slurry was cooled and mixed in a blender. This pulp slurry was used in paper making.

\subsection{Paper making process}

Water was added to the pulp slurry to make a thin mixture according to the treatment (pulp slurry $30 \%$, $50 \%$ and $70 \% \mathrm{v} / \mathrm{v})$. The pulp slurry was stirred and water was drained from the slurry through a plate screen in a tube (12 cm in diameter). The wet paper web is consolidated and transferred to a blotting paper, and press with automatic sheet press (pressure of $3.5 \mathrm{~kg} \mathrm{~cm}$ ${ }^{2}$ for 5 minutes). The blotting paper was then replaced with new blotting paper and the wet sheet of paper was re-pressed. The semi dry handmade paper was transferred to a stainless-steel plate and left to dry at room temperature of $25^{\circ} \mathrm{C}$ and relative humidity of $50 \%$ for overnight. The dried handmade paper was then removed from the plate and hung in a line for further dried by fan dryer for 4 hours. The handmade paper was analyzed for its mechanical (tensile strength and frictional resistance) and physical properties (water absorption, mass density).

The tensile strength of paper was analyzed by a paper tensile strength tester at a crosshead speed of 50 $\mathrm{mm} /$ minute (Thwing-Albert's QC-1000 Materials Testers). The water absorption test was carried out by a COBB tester. It is intended to determine the level of liquid penetration into the paper. The paper sample size was $10 \mathrm{~cm}$ in diameter then slipped on the COBB tester between plate and tube. Water as amount of $100 \mathrm{~mL}$ was poured into the sample and allowed to stand for 10 minutes. Water is then removed from the plate and the wet sample was transferred onto blotting paper and pressed with automatic press machine. The semi-dry sample was re-weighed. The percentage of water absorption (WA) was calculated by the formula as follows:

$$
\mathrm{WA}=\frac{\mathrm{W}_{2}-\mathrm{W}_{1}}{\mathrm{~W}_{1}} \times 100 \%
$$

Where $\mathrm{W}_{1}$ is initial weight of sample $(\mathrm{g})$, and $\mathrm{W}_{2}$ is weight of sample after exposure to water. The density of paper was calculated as weight $(\mathrm{g})$ per $\mathrm{m}^{3}$. Frictional resistance was measured by Mullen Type Bursting Strength Tester. A sample of paper $\left(100 \mathrm{~cm}^{2}\right)$ was clamped and fastened without tension and the tester was turned on. Frictions were set on the specimen until a hole was formed. The value appeared on the screen of display was recorded as frictional resistance.

\section{Results and Discussion}

\subsection{Tensile strength}

The analysis of variance showed that kinds of weeds, concentration of pulp slurry and interaction between kinds of weeds and concentration of pulp slurry had significant effect on tensile strength $(p<0.05)$. Paper with higher value of tensile strength indicated paper is not easily broken when subjected to strain. Paper made of cellulosic fiber of WH produced the highest tensile strength compared to paper made of $\mathrm{WC}$ and BG. Fiber of WH has thin-wall; therefore it is not rigid and it is easily flattened. Thin-walled fiber provides a broad surface for the bonding between the fibers so that the tensile strength increases. Fibers of WH mostly were holocellulose $(83.94 \%)$ and it contained small amount of lignin (3.87\%) during which lignin might be removed during pulping [9]. Lignin in cellulose of WH could be removed by sodium hydroxide hydrolysis [10-11]. Unlike fiber of $\mathrm{WH}$, tensile strengths of paper made of $\mathrm{WC}$ and $\mathrm{BG}$ were 
lower than that of WH. Those fibers have thick-wall and narrow in diameter, therefore they might not interact perfectly inter-fiber and resulted in lower tensile strength. The tensile strength as affected by different fibers type and concentration of pulp added is shown in Figure 1. The tensile strength of paper made of WH fibers was low; therefore WH fibers were added with other materials, such as resin, to form WH fibers composites to increase the tensile strength [12-14].

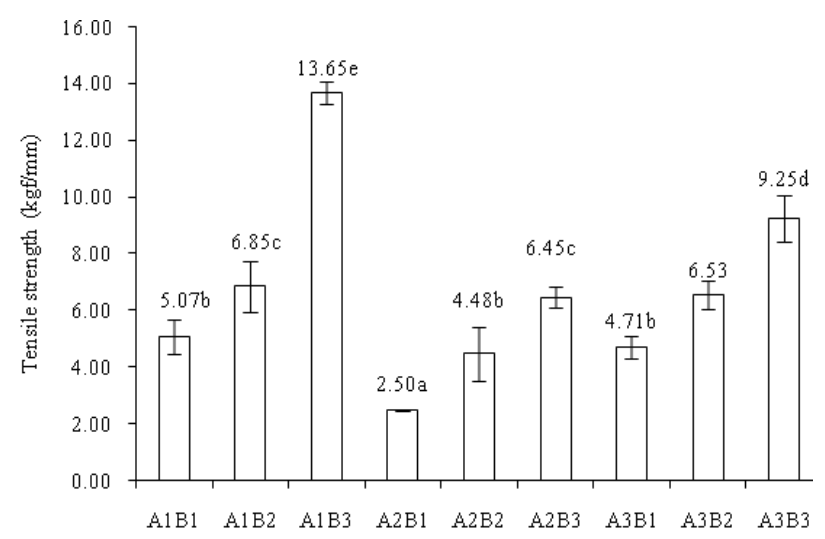

Figure 1. Effect of different fibers origins and concentration of fiber pulp slurry on the tensile strength of paper

\subsection{Frictional Resistance}

Paper frictional resistance is used to determine the strength of paper against frictions. Higher paper frictional resistance indicates high loss of weight on paper during friction. Statistical analysis showed that different types of weeds, concentration of pulp added and the interaction between different types of weeds and concentration of pulp added had significant effect on frictional resistance $(p<0.05)$. The average of paper frictional resistance of paper made of those weeds is presented in Figure 2.

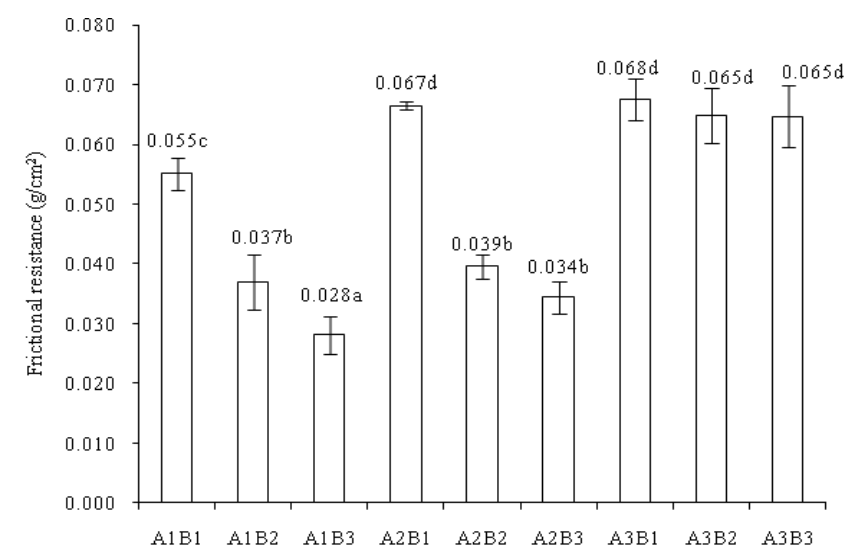

Figure 2. Effect of different fibers origin and concentration of fiber pulp slurry on the frictional resistance of paper
Paper made of fibers of WC resulted in higher value of frictional resistance. It could be due to rough surface of paper; therefore more materials lost during frictioning. On the other hand, the smooth surface on paper made of $\mathrm{WH}$ fiber resulted in a lower value of frictional resistance, as shown in Figure 2.

\subsection{Water Absorption}

Water absorption is a measure of liquid penetration into a paper. Analysis of variance showed that different types of weeds, concentration of pulp added and the interaction between different types of weeds and concentration of pulp added had significant effect on frictional resistance $(p<0.05)$. Higher value of water absorption indicated a lower resistance of a paper against liquid penetration. Paper made of $\mathrm{WH}$ fiber resulted in higher water absorption than that of paper made of $\mathrm{WC}$ and $\mathrm{BG}$, as shown in Figure 3. Fiber of $\mathrm{BG}$ is thick and rigid; therefore the paper is more porous due to the weak internal bonding between fibers. The lowest water absorption was found in paper made of WH which fibers have thin wall and flexible.

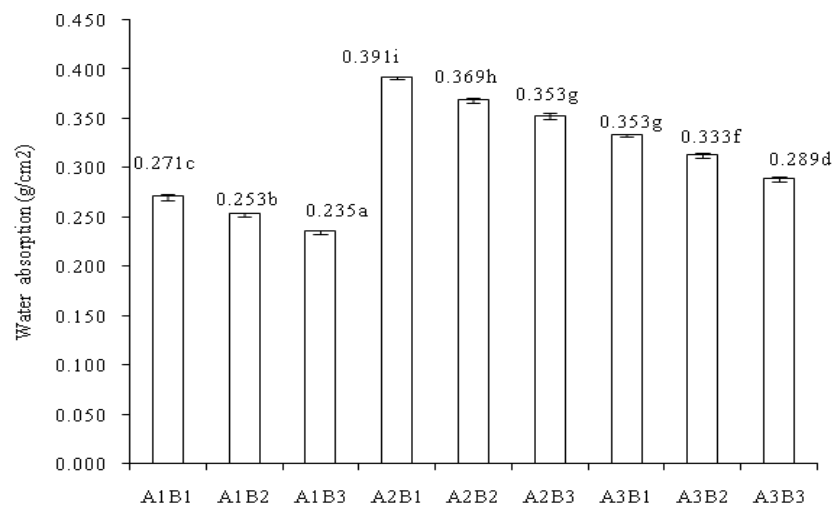

Figure 3. Effect of different fiber origin and concentration of fiber pulp slurry on the water absorption of paper

\subsection{Mass Density}

Mass density is calculated as mass of paper divided by paper volume. The volume was obtained by surface area multiply by paper's thickness. The analysis of variance showed that different types of weeds and concentration of pulp added had significant effect on frictional resistance $(p<0.05)$. On the other hand, the interaction between different types of weeds and concentration of pulp added had no significant effect on frictional resistance $(p>0.05)$. The averages of mass density of all treatments were shown in Figure 4. The highest mass density was found in paper made of WH followed by WC and BG. The higher mass density in paper could be due to more internal bonding between fibers. Higher mass density was found in paper made of 
WH paper. Higher mass density indicates that the paper is condensed which might be due to the strong internal bonding between fibers. As mention earlier that the $\mathrm{WH}$ fibers are soft and therefore the paper is stronger and condensed.

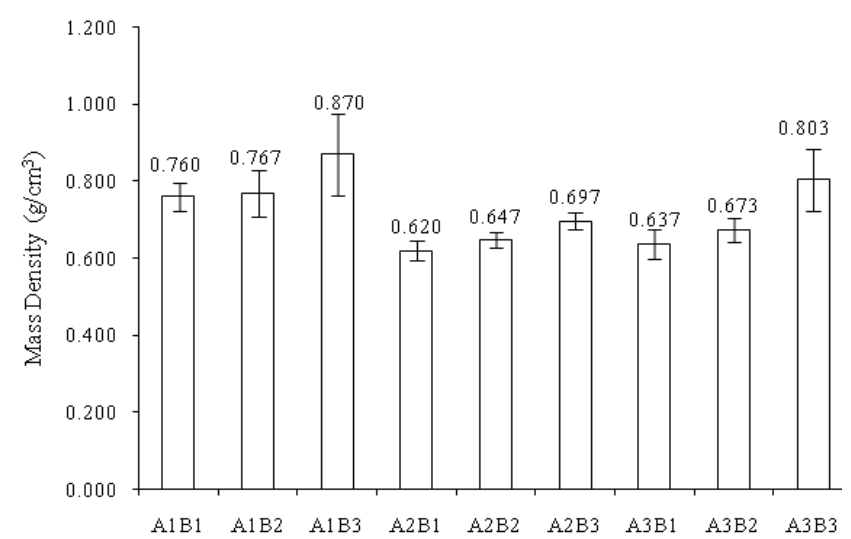

Figure 4. Effect of different fiber origin and concentration of fiber pulp slurry on the mass density of paper

\section{Conclusion}

Water hyacinth (Eicchornia crassipes), water chestnuts (Eleocharis dulcis) and bladygrass (Imperata cylindrica) are potential fiber resources for paper. Among those fiber resources, water hyacinth produced the best paper performance with the properties of 13.65 $\mathrm{kgf} \mathrm{mm}^{-1}$ for tensile strength, water absorption $0.235 \mathrm{~g}$ $\mathrm{cm}^{-2}$, frictional resistance $0.028 \mathrm{~g} \mathrm{~cm}^{-2}$, and mass density of $0.87 \mathrm{~g} \mathrm{~cm}^{-3}$.

\section{Acknowledgement}

The authors are grateful to Universitas Sriwijaya for the facilities for conducting this research.

\section{References}

[1] S.H.C.S. Gunawardana and S. Wijetunga. "Paper production for rough use from aquatic weeds (Limnocharis flava) and its evaluation," in Proc. of the 15th International Forestry and Environment Symposium, 26-27 November 2010. Published by Department of Forestry and Environmental Science, University of Sri Jayewardenepura, Sri Lanka.

[2] S. Asikin and M. Thamrin. "The role of water chestnuts (Eleocharis dulcis) in the ecosystem of swamp rice field". Jurnal Litbang Pertanian, vol. $31 \mathrm{nr} 1$; pp. 35-42. 2012.

[3] P. Aloo, W. Ojwang W, R. Omondi, J.M. Njiru and D. Oyugi. "A review of the impacts of invasive aquatic weeds on the biodiversity of some tropical water bodies with special reference to Lake Victoria (Kenya)". Biodiversity Journal, vol $4 \mathrm{nr}$ 4; pp. 471-482. 2013.
[4] O.Y. Mansour, M.Z. Sefain, M.M. Ibrahim and W.K.E. Zawawy. "Paper coating mixture: preparation, application, and study of their rheological properties". Journal of Applied Polymer Science, vol. 77; pp. 1666-1678. 2000

[5] K. Ichikawa. "Dynamic mechanical properties of polyurethane-urea microcapsules on coated paper". Journal of Applied Polymer Science, vol. 54; pp. 1321-1327. 1994.

[6] M. Karina, H. Onggo and A. Syampurwadi. "Physical and mechanical properties of natural fibers filled polypropylene composites and its recycle". Journal of Biological Sciences, vol. $7 \mathrm{nr}$ 2; pp. 393-396. 2007. ISSN 1727-3048.

[7] L. Ye, A. Zhong, D. Chen and F. Yang F. "Preparation and properties of nanomontmorillonite paper-plastic laminating adhesive". Journal of Applied Polymer Science, vol. 97; pp. 872-877. 2005.

[8] G. Eroglu, J.P. Andreolety JP, J. Silvy and H. Cheradame. "Improvement of paper properties by impregnation in cellulose derivative solution". Acta Polymerica, vol. 34; pp. 178-190. 1980.

[9] T. Tumolva, J. Ortenero and M. Kubouchi. "Characterization and treatment of water hyacinth fibers for NFRP composites." The $19^{\text {th }}$ International Conference on Composite Materials, 28 July-2 August 2013, Montreal, Canada.

[10] S.M. Sandip, M.M. Sandeep and A.N. Aiyaj. "Biochemical conversion of acid-pretreated water hyacinth (Eichhornia crassipes) to alcohol using Pitchia stipitis NCIM3497. International Journal of Advanced Biotechnology and Research, Vol $3 \mathrm{nr}$ 2; pp. 585-590. 2012.

[11] D.P. Singh and R.K. Trivedi. "Acid and alkaline pretreatment of lignocellulosic biomass to produce ethanol as biofuel". International Journal of Chemtech, vol. $5 \mathrm{nr}$ 2; pp. 727-734. 2013.

[12] H. Abral, D. Kadriadi, A. Rodianus, P. Mstariyanto, Ilhamdi, S. Arief, S.M. Sapuan and M.R. Ishak. "Mechanical properties of water hyacinth fibers-polyester composites before and after immersion in water". Materials and Design vol. 58; pp. 125-129. 2014.

[13] I. Taha and G.A. Ziegmann. "A comparison of mechanical properties of natural fiber filled biodegradable and polyolefin polymers". Journal of Composite Materials vol. 40; pp. 1933-46. 2006.

[14] A.G. Supri and H. Ismail. "The effect of NCOpolyol on the properties of low-density polyethylene/water hyacinth fiber (Eichhornia crassipes) composites". Polymer Plastic Technology Engineering vol. 49; pp. 766-71. 2010. 